Jap. J. M. Sc. \& Biol., 15, 1-8, 1962

\title{
TWO-DIMENSIONAL IMMUNOELECTROPHORESIS IN AGAR
}

\author{
MiTsuO YOKOYAMA\# AND MARIETTA CARR \\ Department of Health, Education, and Welfare, Public Health Service, \\ National Institutes of Health, Division of Biologics \\ Standards, Bethesda 14, Maryland
}

(Received : December 26th, 1961)

Many modifications of the agar diffusion technique for the analysis of serum protein components have been developed since the original techniques were described by Oudin (1948) and Ouchterlony (1948). Grabar and Williams (1955) developed a method combining electrophoresis and diffusion of serum proteins in agar and produced precipitin lines using appropriate anti-sera. Various investigators have developed two-dimensional electrophoresis of serum proteins using both paper and starch-gel techniques (Durrhum, 1951 ; Kunkel and Tiselias, 1951 ; Poalik and Smithies, 1958).

The following report is a description of our method of applying two-dimensional electrophoresis to immunoelectrophoresis in agar and results culimating from this method. Two new techniques designed to aid in the identification of the various serum proteins detected by immunoelectrophoresis are also described.

\section{MATERIALS AND METHODS}

Antigen: Pooled normal human group O serum and human serum fractions* I, II+III, II, III, IV-1, IV-4 and V were used as the antigens for immunoelectrophoresis. The serum fractions were diluted to $10 \mathrm{mg}$ per $1 \mathrm{cc}$ with barbital buffer solution.**

Antibody: The anti-human sera were prepared in rabbits by various methods of immunization with pooled human group O serum. "Broad spectrum" anti-human sera were selected and pooled for use in this work.

One-dimensional immunoelectrophoresis: Scheidegger's method (1955) for micro-immunoelectrophoresis was modified. Microscope slides $\left(1^{\prime \prime} \times 3^{\prime \prime}\right)$ precoated with $0.5 \mathrm{cc}$ of $1 \%$ aq. Noble agar and dried at $100^{\circ} \mathrm{C}$ were used. The precoated slide was spread with $1.5 \mathrm{cc}$ of warmed Noble agar diluted to $1.5 \%$ with barbital buffer solution. An antigen well was placed in the middle of each slide by aspirating with a blunt needle of $1 \mathrm{~mm}$ inside diameter after allowing the agar to solidify. The anti-serum was placed on the slide by two methods. In one, Method 1 , a plastic mold, $6.4 \mathrm{~cm}$ long $\times 1 \mathrm{~mm}$ wide was placed at the desired position in the hot agar. After a few minutes when the agar had solidified the mold was carefully removed. After the antigen was electrophoresed anti-serum would be placed in this trough. In the second, Method 2 , after electrophoresis of the antigen, the agar-slide was covered with a $1^{\prime \prime} \times 3^{\prime \prime}$ strip of Whatman No. 1 filter paper impregnated with 0.2 to $0.3 \mathrm{cc}$ of anti-serum.

Two-dimensional immunoelectrophoresis : Microscope slides, $23 / 4^{\prime \prime} \times 23 / 4^{\prime \prime}$, were precoated with $1.5 \mathrm{cc}$ of $1 \%$ aq. Noble agar and dried at $100^{\circ} \mathrm{C}$. Then $5 \mathrm{cc}$ of $1.5 \%$ Noble agar diluted with barbital buffer solution were placed on these slides and an antigen well was aspirated at the center of each agar-slide with a blunt aspirating needle.

\#-Present address : Laboratory of Neurochemistry, National institute of Neurological Diseases and Blindness, National Institutes of Health, Bethesda 14, Maryland.

* Obtained from E. R. Squibb and Sons, New Brunswick, New Jersey.

** The same buffer used for immunoelectrophoresis was used. 
Electrophoresis was performed in the usual manner in one direction and then the slide was turned $90^{\circ}$ and electrophoresis was continued as before with the current causing migration of the serum protein components at right angles to the previous movement.

Two techniques were used to produce precipitin lines. First the entire agar-slide was covered with the same size $\left(23 / 4^{\prime \prime} \times 23 / 4^{\prime \prime}\right)$ Whatman No. 1 filter paper impregnated with $0.5-0.6 \mathrm{cc}$ of anti-serum (Method 3). For the second technique, filter paper strips, approximately 5 mm wide, impregnated with $0.05-0.06 \mathrm{cc}$ of anti-serum were placed along the edges of the slide. Additional anti-serum was added to the filter paper strips when necessary (Method 4). All agar-slides were placed in a humid chamber for 24 hours or longer if necessary and observed for precipitin patterns.

Buffer solution and electric power supply for immunoelectrophoresis: Barbital buffer solution at $\mathrm{pH} 8.6$ and ionic strength 0.05 was used for these experiments. Electrophoretic separation of 1 microliter of antigen was performed at 5 volts per $\mathrm{cm}$ of agar path length for 70 minutes.

\section{RESULTS}

Fig. 1 shows the precipitin pattern and lines of normal human serum and various serum fractions produced by using Methods 1 and 2. Normal human serum produced a precipitin pattern of circles except for the gamma globulin fraction in Method 2 (Fig. 1-a). The albumin fraction can be seen as the largest circular area with sharp edges towards the anode and another sharp edged circle within. The pre-albumin is seen as a single precipitin circle in front of the albumin fraction with some portions of both fractions overlapping. The next spot of precipitin which is clearly demonstrated and connected with the albumin spot is an alpha-1 fraction. The next area shows several circles which can be identified as either an alpha-1 or an alpha-2 fraction. A dark spot appears which is presumed to be an alpha-2 globulin fraction. The beta globulin fractions are near the point of origin although they have migrated in some degree to both the anode and the cathode. The gamma globulin has moved towards the cathode and has developed an elliptical pattern. However, some of the gamma globulin and beta-2 globulin produce another elliptical pattern near the origin.

The position and identity of each human serum fraction prepared by Cohn's method was established by comparison with a precipitin pattern of pooled human serum produced by using Method 1 and Method 2 (Fig. 1-b, c, d and e).

Fig. 2 shows a schematic diagram of the migration of serum protein components using two-dimensional electrophoresis for normal human serum in agar. The pattern has moved to a 45 degree angle on the agar-slide after two-dimensional electrophoresis. Applying antisera by Method 3, normal human serum developed the same pattern as

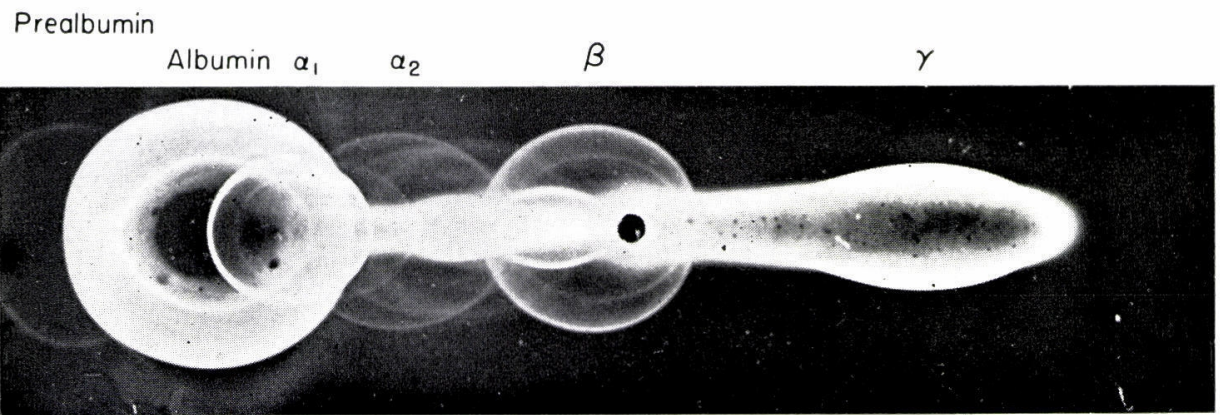

Fig. 1-a. Precipitin pattern of pooled normal human serum produced by using Method 2 . 


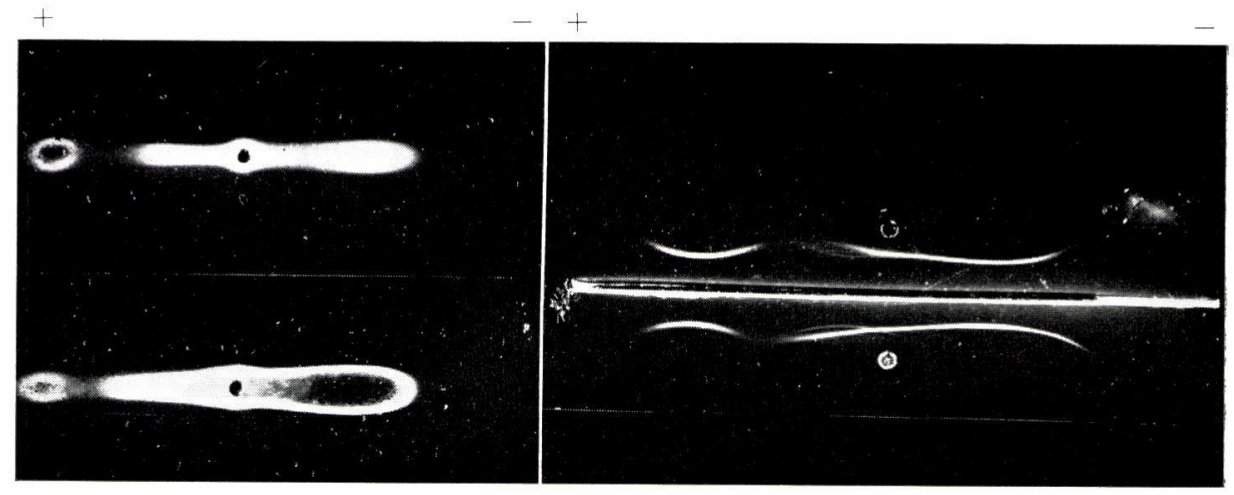

Fig. 1-b. Precipitin patterns of Fraction I (above) and Fraction II + III (below) produced by using Method 1 (right) and Method 2 (left).

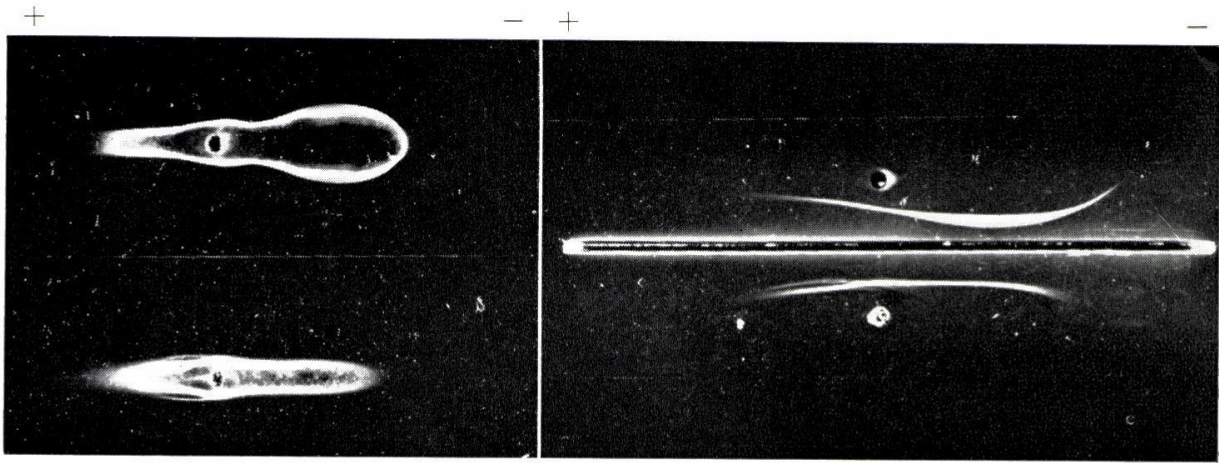

Fig. 1-c. Precipitin patterns of Fraction II (above) and Fraction III below produced by using Method 1 (right) and Method 2 (left).
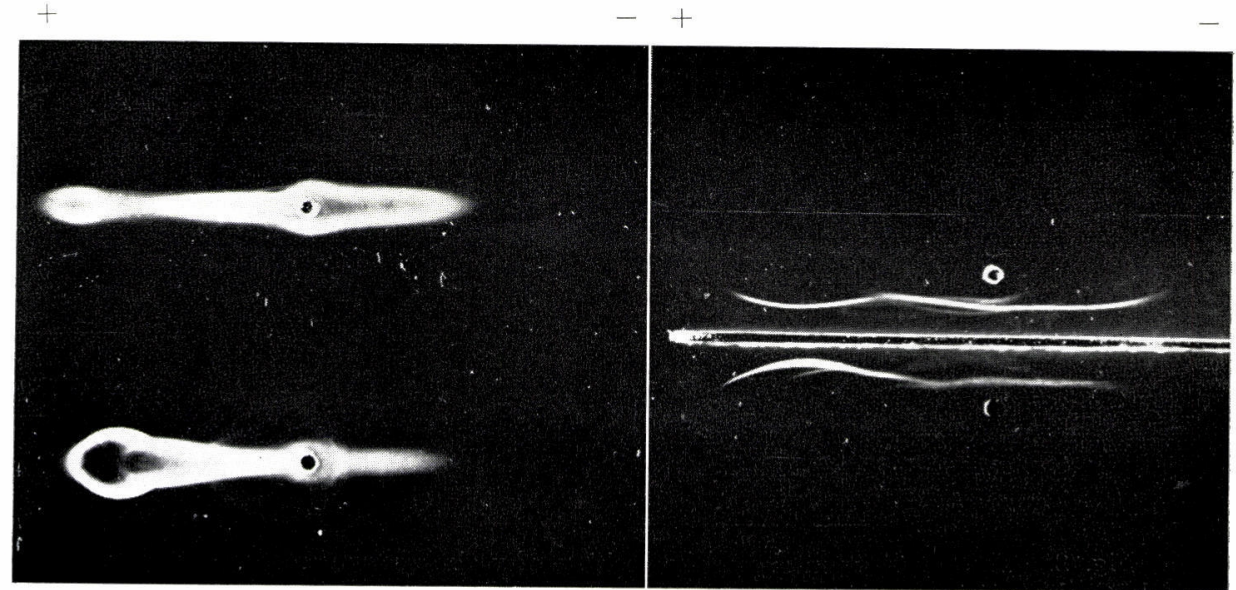

Fig. 1-d. Precipitin patterns of Fraction IV-1 (above) and Fraction IV-4 below produced by using Method 1 (right) and Method 2 (left). 


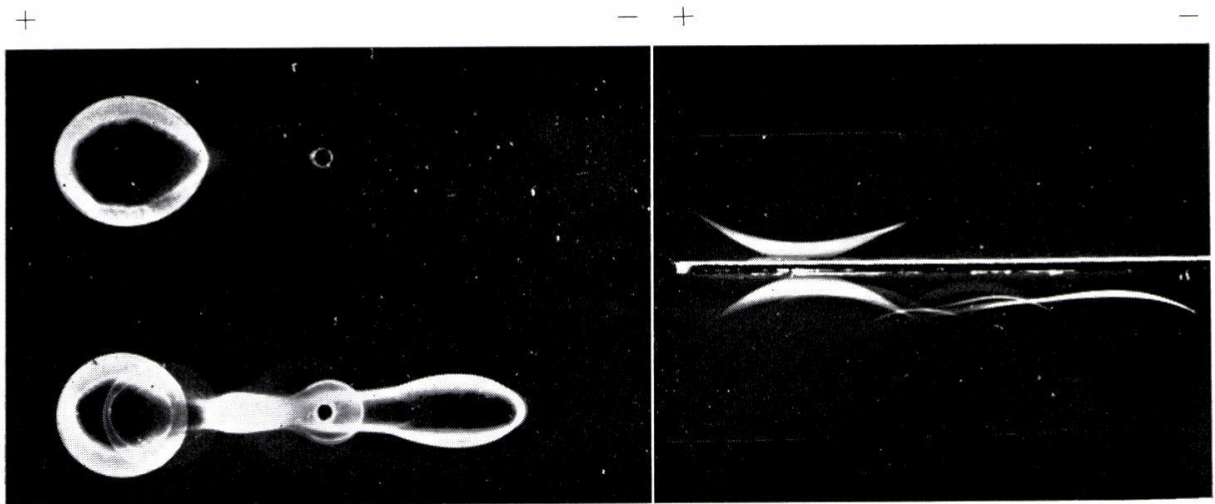

Fig. 1-e. Precipitin patterns of Fraction V (above) and normal human serum (below) produced by using Method 1 (right) and Method 2 (left).

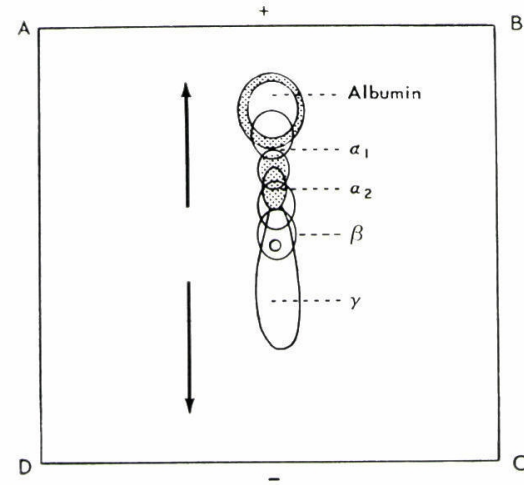

B

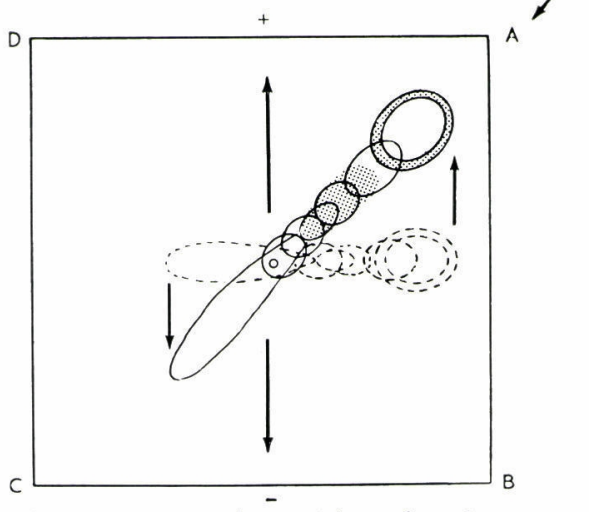

Fig. 2. The top diagram shows the position of various serum components after electrophoresis in one direction. In the figure below the position of the serum components is shown after the slide has been turned and electrophoresis has been performed at right angles to the previous path of migration. 


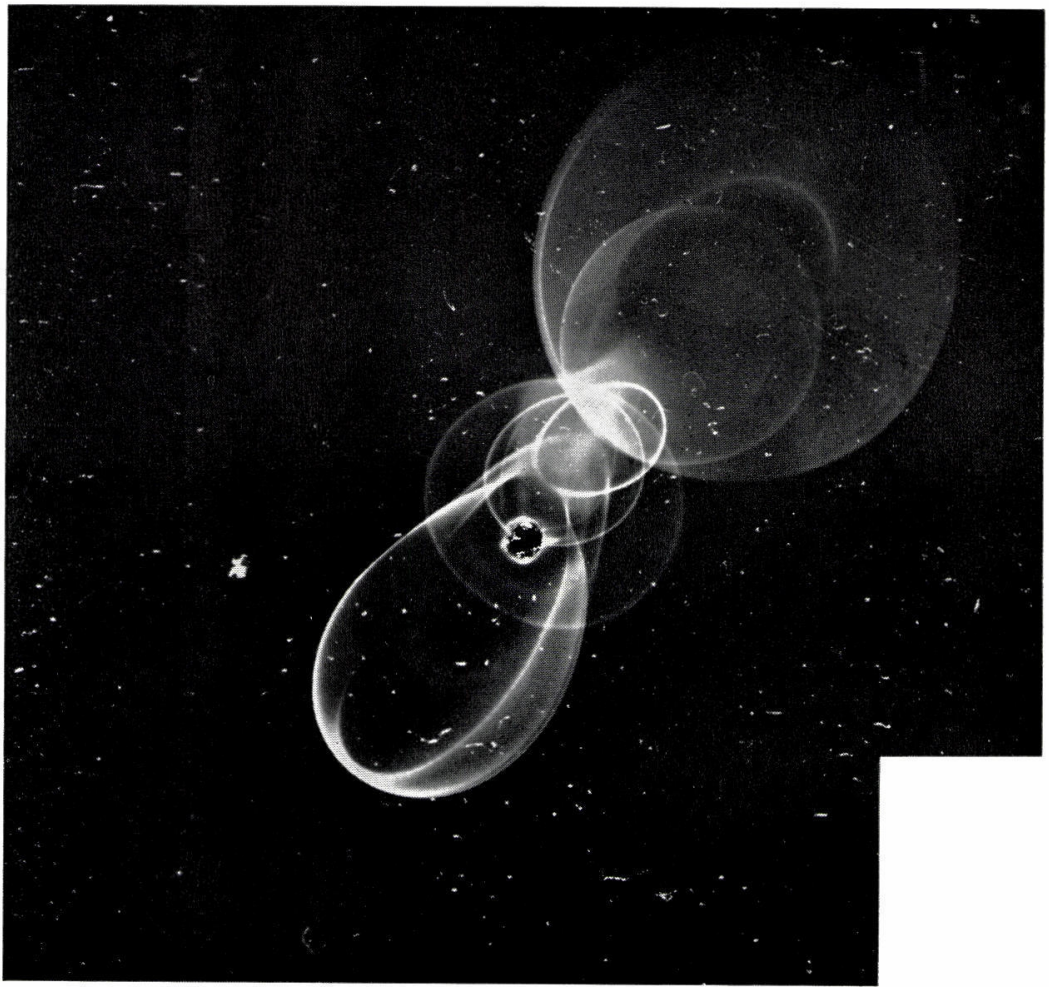

Fig. 3 Precipitin patterns were formed when the anti-human serum was applied by covering the agar-slide with impregnated filter paper (Method 3 .

by Method 2 (Fig. 3).

Fig. 4 is a schematic diagram showing the diffusion of the electrophoresed human serum and the anti-human serum and the precipitin pattern produced by using Method 4. The precipitin lines occur when the antigen and antibody meet at the proper concentration.

Fig. 5 shows precipitin lines of normal human serum reacted with anti-human serum after two-dimensional electrophoresis in agar. The beta globulins which remain near the point of origin have formed a square precipitin line. Albumin and gamma globulin formed more elliptical lines at both sides of the beta globulin reaction. The precipitin lines of alpha globulin were formed within the albumin line. The diagram shows precipitin lines of the main serum fractions.

\section{DisCussion}

In general, serum protein components separated by paper, starch-gel, agar or cellulose acetate electrophoresis are fixed and stained using acetic acid, brom phenol blue solution, or some other similar reagents. However, the use of an anti-serum as in Methods 2 or 3 shows the position of the electrophoresed serum proteins more precisely.

An excess of antibody will produce indistinct and indefinite patterns while insufficient antibody forms weak reactions with resulting excessive diffusion of the components in 

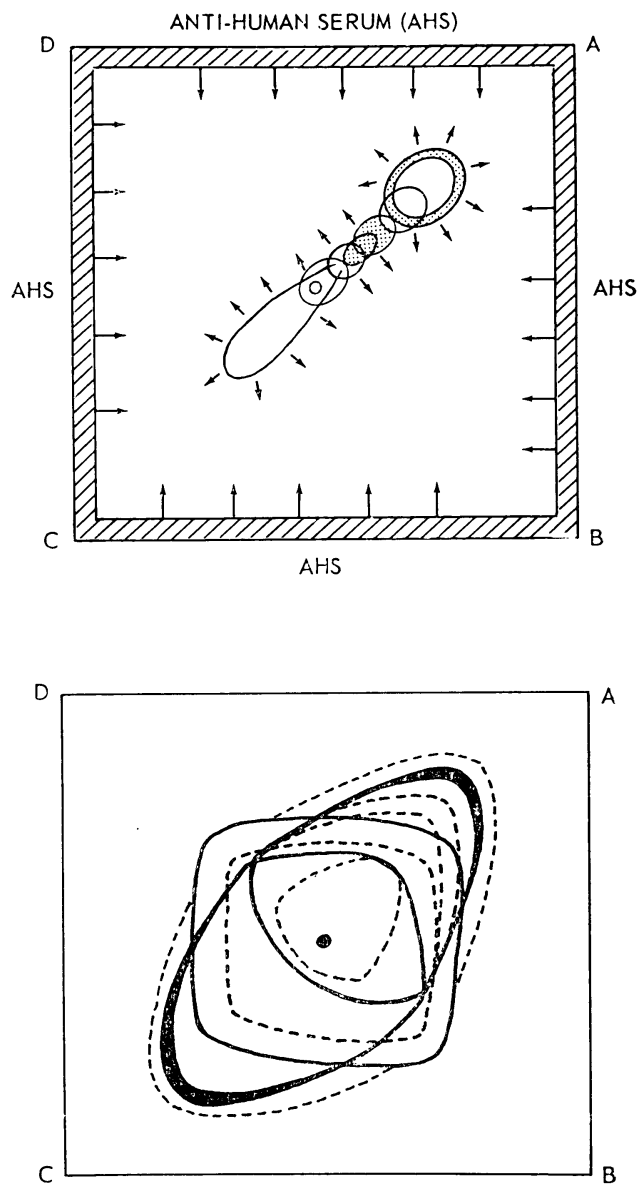

Fig. 4. The arrows in the diagram at the top show the diffusion of the electrophoresed human serum components and the anti-human serum. The diagram below shows the precipitin lines formed when the diffusing antigens and antibodies meet and react.

the agar. Potent and broad spectrum anti-human sera are required to obtain gcod reactions and proper precipitin patterns to identify human serum components.

The location of the serum fractions was clearly demonstrated in two-dimensional electrophoresis by adding the anti-serum to filter paper covering the slides as in Method 3 , but no additional fractions were detected when compared with Method 2. When the anti-serum impregnated filter paper strips were placed along the edges of the slide as in Method 4, however, the following advantages were noted. For example, when two or more components of different molecular size were located in the same area after electrophoresis clearly separated precipitin lines were formed because of differing rates of diffusion in the agar. The identification of serum components having the same electric mobility by varying degrees of curvature and/or by degree of asymmetry as in one dimensional immunoelectrophoresis is often complex and confusing. The numerous precipitin lines in a specific area will interfere with the identification of these compo- 


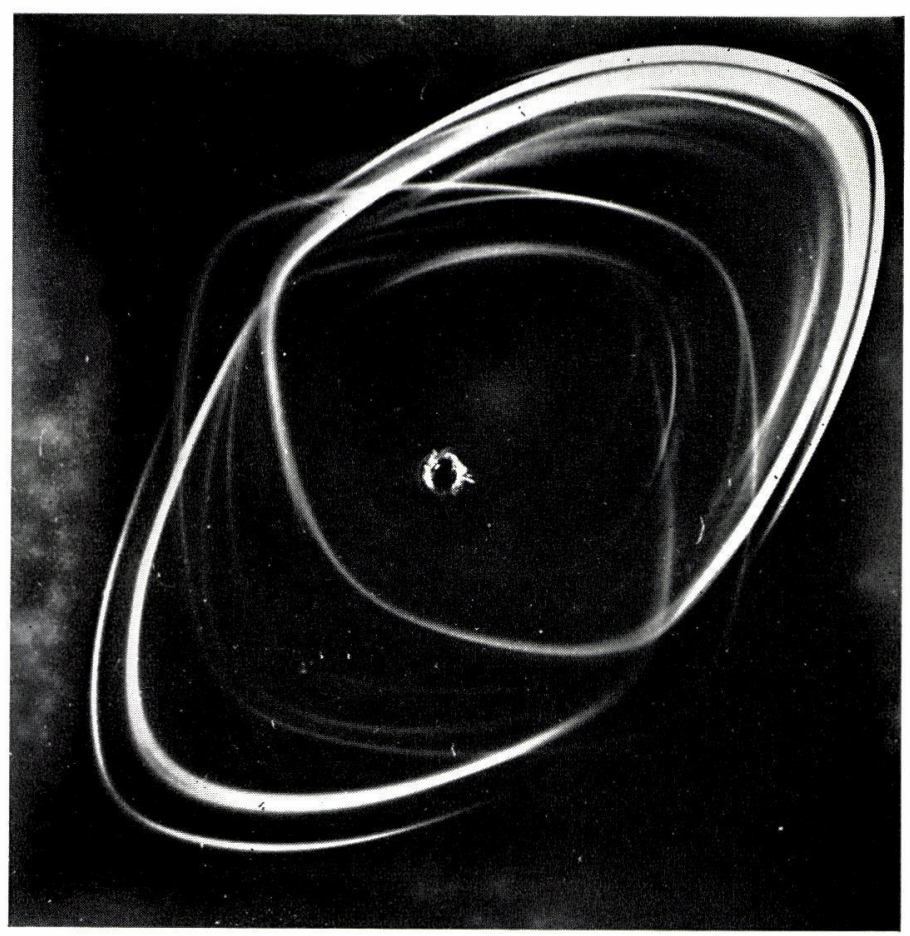

Fig. 5. Precipitin lines show reactions of human serum components and corresponding antibodies. The anti-human serum was placed along the outer edges (Method 4).

nents and in addition the strong or wider precipitin lines are apt to cover up the weak or thin lines. However, the longer distance that antigen and antibody diffuse before a precipitin line is formed in Method 3 allows components of differing molecular size to separate by diffusion and thus form distinct and separate precipitin lines.

Two-dimensional immunoelectrophoresis could also be used to determine whether two anti-sera are identical. Filter paper strips impregnated with one anti-serum would be placed at right angles along two sides of the square slide and two other filter paper strips impregnated with the other anti-serum would be placed along the other two edges. Differences would be shown by disconnected lines or missing precipitin lines.

Much remains to be investigated with this technique. From the results of previous investigations it appears that the use of two buffer systems or changes in $\mathrm{pH}$ and ionic strength will permit separation of even more serum components by two-dimensional electrophoresis in agar.

\section{SUMMARY}

A technique to determine the position and presence of human serum components by electrophoresis in agar was developed. Two dimensional electrophoresis and diffusion were used for a more distinct separation of precipitin lines in agar.

A combination of the first technique and double diffusion of precipitin lines is an improved technique for further detection and identification of serum protein components. 
The authors gratefully acknowledge the valuable assistance of Mr. Frank Caparael, Division of Research Services, Scientific Reports Branch, National Institutes of Health, for preparation of the photographs.

\section{REFERENCES}

DuRrhum, E. L. (1951) . Two dimensional electrophoresis and ionophoresis. J. Colloid Sc., 6, 274-290.

Grabar, P. \& Williams, C. A. (1955) : Méthode immunoélectrophorétique d'analyse de mélanges de substances antigénique. Biochem. Biophys. Acta., 17, 67-74.

Kunkel, H. G. \& Tiselius, A. (1951): Electrophoresis of proteins on filter paper. J. Gen. Physiol., 35, 89-118.

OUCHTERLONY, O. (1948): Diffasion gel methods for immunological analysis prog. Allergy, 5, $1-78$.

OUDIN, J. (1948) : L'analyse immunochimique méthode per diffusion des antigènes au sein de l'immunsérum précipitant gélose. Ann. Inst. Pasteur., 75, 30-51.

Poulik, M. P. \& SMithies, O. (1958) : Comparison and combination of the starchgel and filter paper electrophoretic methods applied to human sera: Two-dimensional electrophoresis. Biochem. J., 68, 636-646.

Scheidegger, J. J. (1955) : Une micro-methode de l'immunoélectrophorèses. Int. Arch. Allergy, $7,103-110$. 